\title{
EFEKTIFITAS AIR REBUSAN DAUN SIRIH DALAM MEMPERCEPAT PENYEMBUHAN LUKA PERINEUM
}

\author{
Ari Christiana \\ Mizam Ari Kurniyanti. \\ STIKES WidyagamaHusada
}

\begin{abstract}
Piper betle contains kavikol which can be used to traditional treatments, such as for deadly germs, antioksidasi, fungicidal and anti fungal. In this research want to known function kavikol who have an antiseptic in expedite the healing of injured perineum on the postpartum which is used at the vulva hygiene. The research method consists of three stages, the first stage is to do the extraction of Piper betle to get kavikol with the technique of boiling it for 10, 15 and 20 min with a temperature of $100 \mathrm{C}$ and perform chemical tests and characteristics. The second stage is the implementation of utilization of kavikol extract for vulvar hygiene on the postpartum against the perineum healing wounds speed. Conclusion the results of the research are the highest levels of kavikol found on the boiling of water decoction of Piper betle with a time of 20 minutes and of the results of the data retrieval as well as observation of the 19 respondents who obtained up to date 9 November obtained data that wound stitches perineum at postpartum mother cured and dry up on day 3-4 post!, as well as no signs of infection, whereas results from interviews with respondents obtained information that respondents said pain in the perineum wound stitches also quickly reduced and feels more kesat. The results obtained from test results $T$ from this research is the significance level of 0.000 so can be drawn the conclusion that the water decoction of leaves of the betel (Piper betle) is effective against speed healing of wounds mother postpartum on perineum
\end{abstract}

Keywords : Piper betle, vulva hygiene, the vulva speed the healing of wound perineum 


\section{ABSTRAK}

Daun sirih (Piper betle) mengandung kavikol yang bisa dimanfaatkan untuk perawatan tradisional, diantaranya untuk mematikan kuman, antioksidasi, fungisida dan anti jamur. Pada penelitian ini ingin diketahui fungsi kavikol yang memiliki daya antiseptic dalam mempercepat penyembuhan luka perineum pada ibu nifas yang dipergunakan saat vulva hygiene.

Metode penelitian terdiri dari tiga tahapan, tahap pertama adalah melakukan ekstraksi daun sirih untuk mendapatkan kavikol dengan teknik perebusan selama 10, 15 dan 20 menit dengan suhu $100^{\circ} \mathrm{C}$ dan melakukan uji kimia dan karakteristik. Tahap kedua adalah implementasi pemanfaatan ekstrak kavikol untuk vulvahygiene pada ibu nifas terhadap kecepatan penyembuhan luka perineum

Kesimpulan hasil penelitian adalah kadar kavikol tertinggi terdapat pada perebusan air rebusan daun sirih dengan waktu 20 menit dan dari hasil pengambilan data serta observasi dari 19 responden yang didapatkan sampai dengan tanggal 9 Nopember didapatkan data bahwa luka jahitan perineum pada ibu nifas sembuh dan mengering pada hari ke 3-4 post partum serta tidak ada tanda-tanda infeksi, sedangkan dari hasil wawancara dengan responden didapatkan informasi bahwa responden menyatakan nyeri pada luka jahitan perineum juga cepat berkurang dan terasa lebih kesat. Hasil yang didapatkan dari hasil uji $T$ dari penelitian ini adalah tingkat signifikasi sebesar 0,000 sehingga dapat ditarik kesimpulan bahwa air rebusan daun sirih (Piperbetle) efektif terhadap kecepatan penyembuhan luka perineum pada ibu nifas

\section{Kata kunci : Daun Sirih, vulva hygiene, kecepatan penyembuhan luka perineum}

\section{PENDAHULUAN}

Angka Kematian Ibu (AKI) di Indonesia pada data SDKI tahun 2007 masih tinggi jumlahnya mencapai 228 per 100.000 Kelahiran Hidup. Penyebab langsung kematian ibu antara lain karena infeksi setelah persalinan pada post partum. Dari data yang telah diperoleh infeksi menduduki tingkat ke-2 (dua) dari penyebab kematian ibu, dengan perkiraan persalinan di Indonesia setiap tahunnya sekitar 5.000.000 jiwa dapat dijabarkan bahwa Angka Kematian Ibu sebesar 19.500 s/d 20.000 setiap tahunnya atau terjadi setiap $26 \mathrm{~s} / \mathrm{d} 27$ menit, penyebab kematian tersebut yaitu perdarahan $30 \%$, infeksi 22,5\% dan eklampsi 2,0\%. Infeksi yang sering terjadi pada ibu setelah melahirkan adalah infeksi pada perineum. Infeksi ini ditandai dengan nyeri atau rasa sakit di daerah perineum yang dialami oleh ibu setelah melahirkan. (Wulandari, 2008). Dari sebuah penelitian pada 341 ibu nifas, $16 \%$ mengalami infeksi berkepanjangan pada perineum (Br I Nurs. 2012).

Kurangnya pengetahuan ibu tentang cara pemeliharaan perineal (vulva hygiene) yang benar adalah salah satu penyebab terjadinya infeksi pada perineum. Vulva hygiene pada perawatan perlukaan jalan lahir ada dua macam yaitu perawatan non antiseptik salah satunya yaitu dengan menggunakan pengobatan tradisional yang menggunakan rebusan daun sirih (Piper betle ). Air rebusan dari daun sirih dapat 
digunakan untuk membantu pengobatan luka karena rebusan daun sirih mengandung zat-zat kimia dan antibiotik yang sangat besar manfaatnya (Ambarwati, 2008).

Komponen utama minyak atsiri terdiri dari fenol dan senyawa turunannya. Salah satu senyawa turunan itu adalah kavikol yang memiliki daya bakterisi dalima kali lebih kuat dibanding kanfenol. Daya antibakteri minyak atsiri daun sirih disebabkan oleh adanya senyawa kavikol yang dapat mendenaturasi protein sel bakteri (Ambarwati, 2008).

Dalam penelitian ini dipilih daun sirih sebagai salah satu alternatif bahan yang digunakan untuk vulva hygiene terhadap kecepatan penyembuhan luka perineum. Daun sirih tersebut akan di ekstrak dengan cara direbus selama 10, 15 dan 20 menit selanjutnya mengukur kandungan kavikol yang ada dalam ekstrak daun sirih tersebut untuk digunakan vulvahygiene pada ibu nifas yang mengalami luka perineum.

Penelitian ini bertujuan :

1. Membuktikan bahwa kandungan kavikol dalam ekstrak daun sirih dapat mempercepat penyembuhan luka perineum

2. Menentukan komposisi kavikol dalam ekstrak daun sirih yang mempercepat penyembuhan luka perineum.

\section{METODE PENELITIAN}

Tahap pertama pelaksanaan penelitian ini adalah adanya proses perlakuan dari daun sirih hijau dimana sebagian dilakukan proses pengeringan dengan oven menggunakan suhu $60^{\circ} \mathrm{C}$ (perlakuan 1) sehingga dihasilkan daun sirih kering dengan kandungan airnya $14 \%$ dan sebagian lagi tanpa pengeringan (perlakuan 2) sehingga daun sirihnya masih basah. Pada kedua hasil perlakuan tersebut dilakukan pengeringan lagi sehingga menghasilkan 2 bentuk yaitu Pasta(hasil pengeringan dri perlakuan 1) dan Pati (hasil pengeringan perlakuan 2). Dari hasil pengeringan tersebut kemudian dilakukan perebusan dengan air menggunakan suhu $100^{\circ} \mathrm{C}$ selama 10 menit, 15 menit, dan 20 menit, masingmasing hasil dari perebusan selang waktu tersebut dilakukan pemisahan antara ampas dengan hasil ekstrasi sehingga menghasilkan ekstraksi kavikol yang berbeda-beda. Dilakukan uji kimia kavikol untuk menentukan kadar kavikol tertinggi dari ketiga kelompok waktu tersebut.

Sedangkan pada tahap kedua dilakukan implementasi atau pelaksanaan eksperimen penggunaan kavikol tertinggi sebagai bahan untuk vulvahygiene pada ibu nifas dalam mempercepat penyembuhan luka perineum. Penelitian di lakukan pada ibu nifas di BPM Wilayah Kabupaten Malang dengan teknik analisis observasiona 
1.

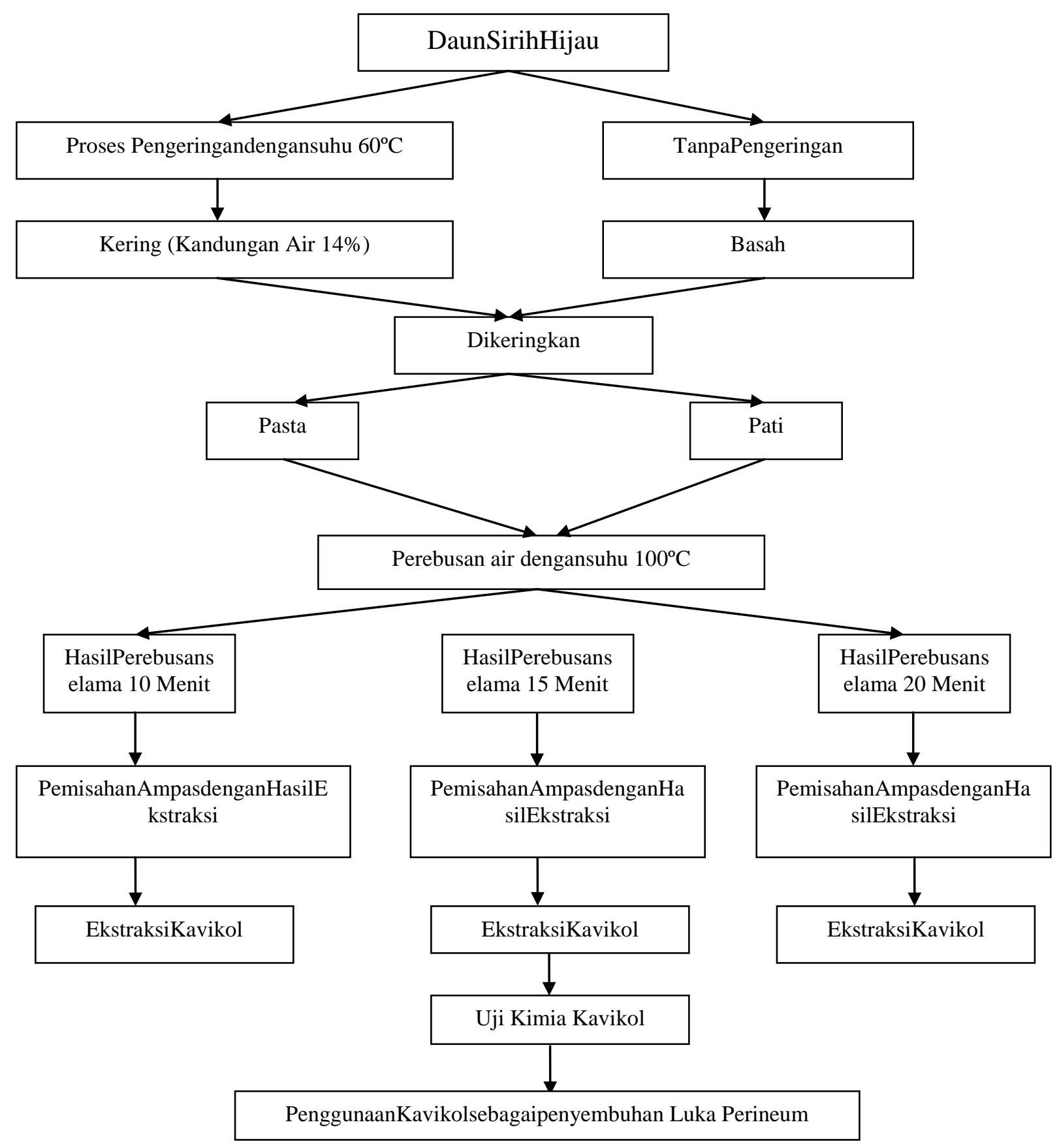

Gambar 1 Tahapan Pelaksanaan Penelitian 


\section{HASIL PENELITIAN}

Hasil sementara yang dicapai pada penelitian ini adalah :

1. 2 sampel daun sirih hijau (Piper betle) masing-masing telah dilakukan proses pengeringan dengan oven (suhu $60^{\circ} \mathrm{C}$ ) dan dengan proses pengeringan pada udara biasa. Selanjutnya masing-masing sampel direbus pada suhu $100^{\circ} \mathrm{C}$ selama 10 menit, 15 menit dan 20 menit. Setelah melalui proses pendinginan hasil perebusan berupa ekstrak daun sirih di lakukan uji kimia untuk mengetahui kandungan kavikol dari masing-masing sampel. Dari hasil uji laboratorium didapatkan bahwa kandungan kavikol tertinggi didapatkan pada sampel ekstrak daun sirih yang telah di oven dengan suhu $60^{\circ} \mathrm{C}$ dan direbus selama 20 menit. Hasil ekstraksi dengan kandungan kavikol tertinggi inilah yang dipergunakan sebagai bahan penelitian untuk penyembuhan luka jahitan perineum.

2. Ekstraksi daun sirih dengan kadar kavikol tertinggi digunakan sebagai bahan penelitian kepada 19 responden. Ekstraksi daun sirih tersebut diberikan kepada masing-masing responden sebagai bahan untuk vulvahygiene dan seluruh responden tidak mendapatkan perlakuan secara kimiawi, misalnya luka jahitan dikompres dengan betadine. Sampai dengan tanggal 9 Nopember didapatkan 19 ibu nifas dan telah dilakukan perlakuan serta observasi pada luka jahitan perineum. Dari hasil observasi diketahui bahwa luka jahitan perineum pada ibu nifas sembuh dan mengering pada hari ke 3-4 post partum serta tidak ada tanda-tanda infeksi. Sedangkan dari hasil wawancara dengan responden didapatkan informasi bahwa responden menyatakan nyeri pada luka jahitan perineum juga cepat berkurang dan terasa lebih kesat

3. Hasil yang didapatkan dari hasil uji T dari penelitian ini adalah tingkat signifikasi sebesar 0,000 sehingga dapat ditarik kesimpulan bahwa air rebusan daun sirih (Piperbetle) efektif terhadap kecepatan penyembuhan luka perineum pada ibu nifas.

\section{KESIMPULAN}

Kesimpulan sementara dari hasil yang dicapai saat ini adalah kadar kavikol tertinggi terdapat pada perebusan air rebusan daun sirih dengan waktu 20 menit dan dari hasil pengambilan data dan observasi dari 19 responden yang di dapatkan sampai dengan tanggal 9 Nopember di dapatkan data bahwa luka jahitan perineum pada ibu nifas sembuh dan mengering pada hari ke 3-4 post partum serta tidak ada tandatanda infeksi. Sedangkan dari hasil wawancara dengan responden didapatkan informasi bahwa responden menyatakan nyeri pada luka jahitan perineum juga cepat berkurang dan terasa lebih kesat. Hasil yang didapatkan dari hasil uji $\mathrm{T}$ dari penelitian ini adalah tingkat signifikasi sebesar 0,000 sehingga dapat ditarik kesimpulan bahwa air rebusan daun sirih (Piperbetle) efektif terhadap kecepatan penyembuhan luka perineum pada ibu nifas.

\section{DAFTAR PUSTAKA}

Ambarwati, E. 2008. Asuhan Kebidanan Nifas. Yogyakarta: MitraCendekia. Agusthin. 2011. Percepatan Kesembuhan Luka Perineum antara Perawatan menggunakan dan tidak menggunakan kompres antiseptik. Diakses tanggal 11 April 2012, From : www.grahacendikia.com 
Arawwawala LD, Hewageegana HG, et al.2011. Standardization of spraydried powder of Piper betle hot water extract.Pharmacogn Mag. 2011 Apr;7(26):157-60.

Arif, Fauzi. 2009. Aneka Tanaman Obat dan Khasiatnya. Jakarta : PT Buku Kita

Ari Yudhiarti. 2008. KhasiatBuah, Rempah Rempah Untuk Pengobatan. Jakarta :Cicilai IQ Media

Diah, Wulandari. 2010. Asuhan Masa Nifas.Yogyakarta :NuhaMedika

Eny, Retna. 2008, Asuhan Kebidanan Nifas. Yogyakarta : Nuha Medika

Ganguly S, Mula S, Chattopadhyay S, et al. 2007. An ethanol extract of Piper betle Linn. mediates its antiinflammatory activity via downregulation of nitric oxide. I Pharm Pharmacol. 2007 May;59(5) : 711-8.

Jhpiego.2003. Panduan Pengajaran Pencegahan infeksi. Jakarta : Pusdiknakes.

Johnson A Thakar R, et al. 2012. Obstetric perineal wound infection: is there underreporting?.Br I Nurs. 2012 Mar 8-21;21(5):S28, S30, S32-5.

Johnson, Ruth. 2005. Buku Ajar Praktek Kebidanan. Jakarta. ECG

JNPK. 2004. Panduan Pencegahan Infeksi Untuk Fasilitas Pelayanan Kesehatan Dengan Sumber Daya Terbatas. Jakarta : Sarwono Prawiroharjo.

Khaidir, M. 2009. Asuhan Keperawatan Dengan Infeksi Nifas. Jakarta : Salemba Medika.

Mochtar, R. 2006. SinopsisObstetri. Jakarta: ECG.

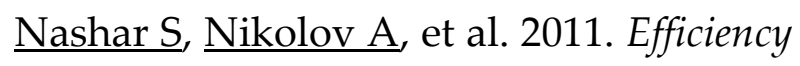
of Cikatridina spray for healing of episiotomy and perineal ruptures. 2011. AkushGinekol (Sofiia). 2011;50(3):20-5.
Prima, Dewi. 2008. Ramuan Herbal DaunSirih.Jakarta :Shira media. Rini Damayanti. 2003 Khasiat dan Manfaat daun sirih. Jakarta : PT Agromedia pustaka.

Riwidiko, Adi. 2005. Statistik Kesehatan. Yogyakarta : Mitra Cendikia

Setiawan, Dalimartha. 2006. Atlas Tumbuhan Obat Indonesia. Jakarta : Wisma Hijau

Samba, Suharyati, 2005. Buku Ajar Kebidanan. Jakarta : EGC

Saleha, S. 2009. Asuhan Kebidanan Pada Masa Nifas. Jakarta: Salemba Medika

Silvinna. 2009. Infeksi Nifas Post Partum. Diakses pada tanggal 11 April 2012 From :www.file.wordpress.com

Sulistyawati, A. 2009. Buku Ajar Asuhan Kebidanan Pada Ibu Nifas. Yogyakarta: Andi Offset.

Samba, Suharyati, 2005. Buku Ajar Kebidanan. Jakarta : EGC

Septi. 2009. Sirih Pinang Sirih . Diaksestanggal 16 April 2012. From :www. Sinarharapan.com

Shitut S, Pandit V, et al. 1999. The antimicrobial efficiency of Piper betle Linn leaf (stalk) against human pathogenic bacteria and phytopathogenic fungi.Cent Eur I Public Health. 1999 Aug;7(3):137-9. Sunarsih.2011. Harum Vagina Dengan Rebusan Daun Sirih.Diakses tanggal $12 \quad$ April 2012. From :www.ramuantradisional.com 